\title{
STUDIES UPON OBESITY: THE SOURCE OF HEAT DURING PERIODS OF REDUCTION
}

\author{
BY EDWARD H. MASON \\ (From The University Clinic, The Royal Victoria Hospital, and the Medical Department, \\ McGill University, Montreal)
}

(Received for publication September 2, 1926)

The term antiketogenesis was introduced into the American from the German literature by Woodyatt (1) when reporting experimental studies with glycol aldehyd and glycerin aldehyd in a imited number of cases of severe diabetes mellitus. He suggested that as the basis of antiketogenesis there was a little understood reaction between one molecule of acetoacetic acid and one molecule of glucose or alcohol. Later Woodyatt (2) discussed Zeller's experiments on the feeding of iso-caloric low protein diets and Lusk's views on the fatty acid-glucose molecular ratio. The latter concluded that, omitting protein metabolism, six molecules of higher fatty acid required at least two molecules of glucose for its complete oxidation. Lusk (3) in re-calculating Zeller's experiments, suggested that one triose molecule might be sufficient for the complete oxidation of one molecule of a higher fatty acid.

Shaffer (4) in 1920 reported a series of in vitro experiments, based upon the oxidation of acetoacetic acid by hydrogen peroxide in the presence of glucose, from which he concluded that one molecule of glucose is necessary for the complete oxidation of one molecule of acetoacetic acid. Woodyatt (5), working with diabetic patients under standard conditions in which he was able to determine the foodstuffs actually catabolized with a considerable degree of accuracy, concluded that the ratio as then stated by Shaffer was in accordance with his results.

That the molecular ratio of 1:1 might be too low was indicated by the work of Wilder and Winter (6) who investigated the threshold of ketogenesis in sixteen patients; thirteen diabetics and three cases of epilepsy. They concluded that "the ratio between the ketogenic and 
glucose molecules at which a clinically significant ketosis appears has a value of at least 2:1." The probability of this higher ratio was subsequently supported by Shaffer (7) based upon in vitro experiments and calculations of the expected excess of ketogenic molecules in cases of marked ketosis. Employing his earlier molecular ratio of 1:1 Shaffer found that in the presence of marked ketosis the acetone bodies actually found were considerably in excess of that predicted by calculation. This fact he believed indicated an error in the earlier ratio which was supported by later in vitro experiments indicative that one molecule of glucose is capable of oxidizing two molecules of keto-acid when the latter is present in excess. Applying a ratio of 1:2 calculations on suitable cases from the literature predicted less acetone than was actually found. In order to correct this discrepancy Shaffer suggested that protein yielded more ketogenic material than formerly estimated. By increasing the ketogenic factor from protein by $\mathbf{5 0}$ per cent his calculations showed much better agreement.

More recently Harding and Allin (8) have reported a series of experiments to determine the threshold of ketonuria in normal pregnant women. Employing the factors used by Shaffer (4) in his first ratio they found that on the whole the molecular ratio of 1 to 1 held in pregnancy the same as in the non-pregnant condition. Nevertheless it was noted that ratios up to $1: 1.47$ resulted in no greatly increased excretion of acetone bodies.

\section{EXPERIMENTAL STUDIES}

In the study of a series of cases of obesity undergoing reduction through the means of a sub-caloric diet, it became evident that an extreme percentage of their calories were being derived from their body fat, and that this was taking place without any ketosis developing after the first ten days of the restricted diet.

In this communication are recorded the data upon five such cases of so-called "exogenous" obesity maintained continuously in the hospital for a prolonged period of time upon a sub-caloric diet. They were not confined to bed, but exercised daily, and three times per week were given hydrotherapy treatments. In no case after the tenth day of the sub-caloric diet was there any evidence of ketosis as determined by daily urinary ferric chloride tests, and frequent plasma $\mathrm{CO}_{2}$ capac- 
ity determinations. In the tabulation of the data it was found to be convenient to record it in consecutive ten day periods as will beseen in the subsequent tables.

\section{ANALYTICAL METHODS}

All urines were collected in 24-hour periods and preserved under toluol. Total nitrogen was determined by the Kjeldahl-Gunning method. $\mathrm{CO}_{2}$ capacities on the blood plasma were done according to Van Slyke's technique.

\section{CALCULATION OF RESULTS}

Data were obtained which enabled one to calculate with a considerable degree of exactness the mixtures of foodstuffs oxidizing in their bodies.

1. Total metabolism. The total calories produced were assumed to be 20 per cent greater than the level of the basal metabolism. This estimate was considered to be very conservative in view of the fact that all the patients were dressed and active throughout the day, and were given hydrotherapy three times each week. Since the basal metabolic rate was determined at least twice each week an accurate calculation could be made of the average basal heat production in ten day periods.

2. Protein combustion. The protein oxidized was calculated from the urinary nitrogen which was actually determined, adding 5 per cent for the stool nitrogen. The assumption that only 5 per cent of the total nitrogen excreted was lost by the stool was considered to be justified in view of the very low diets. The factor 26.51 was used for converted grams of nitrogen into protein calories.

3. Carbohydrate combustion. Since the first five to ten days of the low diets were excluded the assumption that the glycogen deposits were appreciably reduced was made, and the carbohydrate oxidized calculated as being derived only from the intake. The food carbohydrate was figured from Atwater and Byrant's average values, each gram being estimated to yield 4.1 calories.

4. Fat combustion. The calories derived from fat were calculated as the difference between the total calories produced and the sum 
of the protein and carbohydrate calories. The fat calories were converted into grams of fat oxidized by the factor 9.3, which factor was considered to be most suitable since the major part of the fat oxidized came from the patient's own tissues.

5. The ketogenic antiketogenic ratio. The calculation of the ketogenic antiketogenic ratio was made upon the first set of values as given by Shaffer (4), in which the assumption was made that one molecule of glucose is antiketogenic for one molecule of acetoacetic acid.

\begin{tabular}{|c|c|c|}
\hline & Ketogenic & Antiketogenic \\
\hline & $m M$ & $m M$ \\
\hline 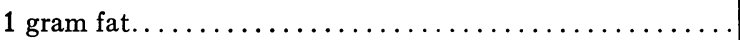 & 3.43 & 0.57 \\
\hline 1 gram glucose $\ldots \ldots \ldots \ldots \ldots \ldots \ldots \ldots$ & 0.00 & 5.56 \\
\hline 1 gram $N$ (Urine plus stool) $\ldots \ldots \ldots \ldots \ldots$ & 10.00 & 20.00 \\
\hline
\end{tabular}

TABLE 1

Loss of weight during reduction

\begin{tabular}{|c|c|c|c|c|c|c|c|c|}
\hline \multirow{2}{*}{ Case } & \multirow{2}{*}{ Sex } & \multirow{2}{*}{ Age } & \multicolumn{2}{|c|}{ Weight } & \multirow{2}{*}{ Total loss } & \multirow{2}{*}{ Total loss } & \multirow{2}{*}{ Days } & \multirow{2}{*}{$\begin{array}{l}\text { Loss per } \\
\text { day }\end{array}$} \\
\hline & & & Admission & Discharge & & & & \\
\hline & & years & $\mathrm{kgm}$. & kgm. & $\mathrm{kgm}$. & pounds & & $\mathrm{kgm}$. \\
\hline I (El) & F. & 36 & 112.5 & 92.4 & 20.1 & 44.2 & 63 & 0.318 \\
\hline II (Ro) & F. & 51 & 172.9 & 138.2 & 34.7 & 76.3 & 90 & 0.386 \\
\hline III $(\mathrm{Ho})$ & F. & 50 & 149.1 & 124.8 & 24.3 & 53.5 & 64 & 0.380 \\
\hline IV $(\mathrm{Ki})$ & F. & 31 & 123.6 & 87.5 & 36.1 & 79.4 & 108 & 0.334 \\
\hline$V(\mathrm{Kr})$ & $\mathrm{F}$. & 29 & 109.9 & 78.6 & 31.3 & 68.9 & 117 & 0.268 \\
\hline
\end{tabular}

Loss of weight during reduction. As seen in table 1, the total loss of weight varied from 20.1 to $36.1 \mathrm{kgm}$. The loss per day paralleled the initial weight directly, being greatest with thelargest initial weight.

Food intake during reduction. The diet administered to each case during the experimental periods of ten days each is shown in table 2 . In cases II and III the first ten days; in cases I and V the first nine days; and in case IV the first five days of the sub-caloric diets have been excluded. In all cases the type of diet during the periods excluded was the same as that during the first accepted ten day periods. 


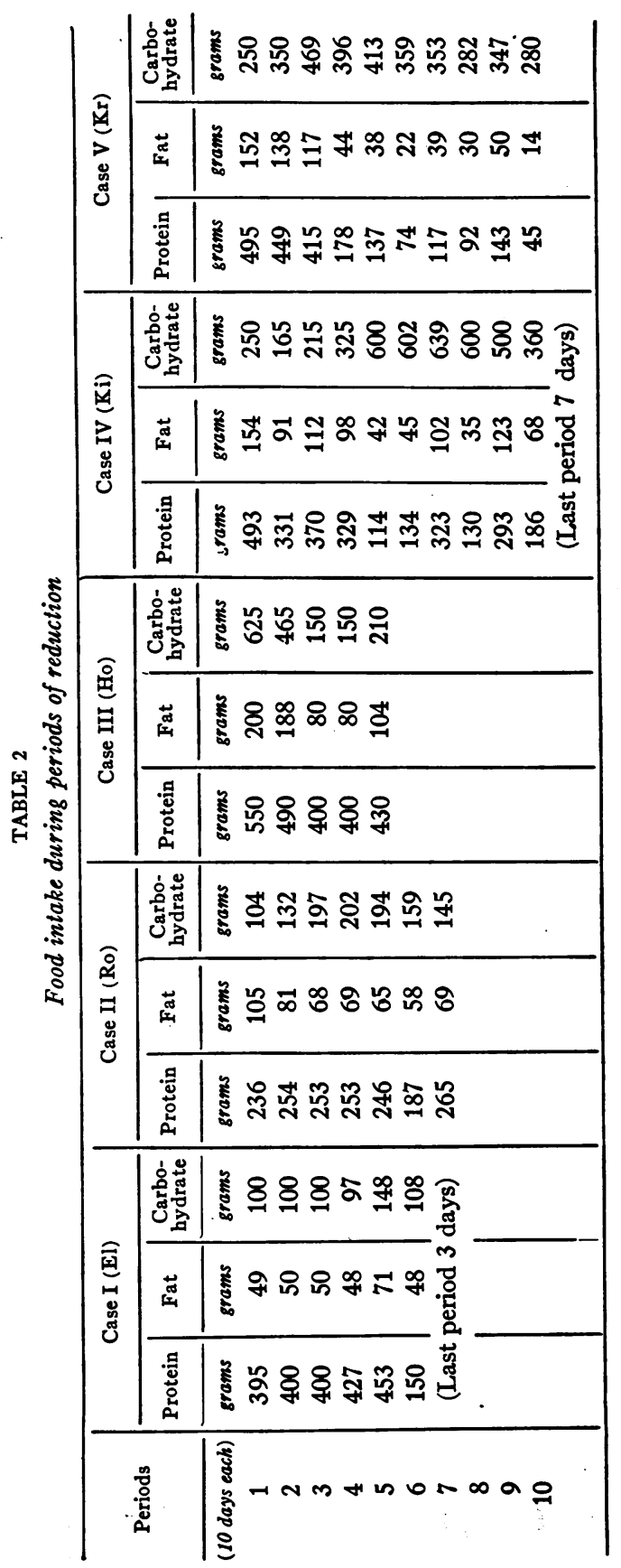

THE JOURNAL OF CLINICAL INVBgTigation, vOL. IV, NO. 1 


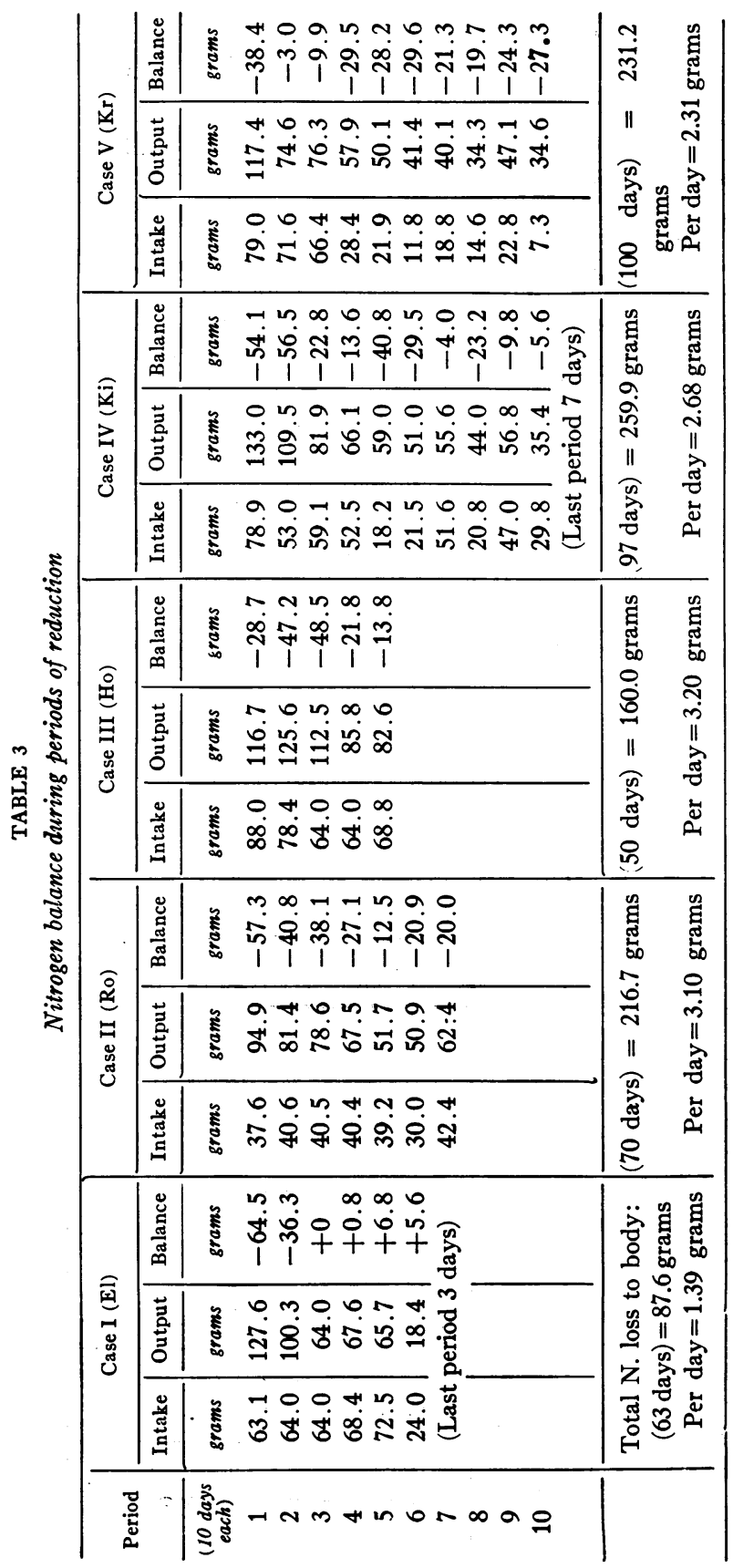


Its extreme sub-caloric nature and duration would tend to add accuracy to the calculations and especially to the assumption that the glycogen deposits were largely exhausted.

Nitrogen balance during reduction. The total nitrogen loss to the body varied from 1.39 to 3.20 grams per day as shown in table 3 . In case I a slightly positive nitrogen balance was maintained during the last thirteen days of the experimental period. This was associated with a falling basal metabolic rate, the average basal production of calories in the six consecutive periods being, 1694, 1597, 1582, 1537,

TABLE 4

Source of heat during periods of reduction

\begin{tabular}{|c|c|c|c|c|c|c|c|c|c|c|c|c|c|c|c|}
\hline \multirow{3}{*}{$\begin{array}{l}\text { Period } \\
10 \text { days each }\end{array}$} & \multicolumn{15}{|c|}{ Percentage of total calories (basal plus 20 per cent) from: } \\
\hline & \multicolumn{5}{|c|}{ Protein } & \multicolumn{5}{|c|}{ Fat } & \multicolumn{5}{|c|}{ Carbohydrate } \\
\hline & $\begin{array}{c}\text { Case } \\
\text { I }\end{array}$ & $\begin{array}{l}\text { Case } \\
\text { II }\end{array}$ & $\begin{array}{c}\text { Case } \\
\text { III }\end{array}$ & $\begin{array}{c}\text { Case } \\
\text { IV }\end{array}$ & Case & $\underset{I}{C}$ & $\begin{array}{c}\text { Case } \\
\text { II }\end{array}$ & $\begin{array}{c}\text { Case } \\
\text { III }\end{array}$ & $\left|\begin{array}{c}\text { Case } \\
\text { IV }\end{array}\right|$ & Case & $\left|\begin{array}{c}\text { Case } \\
\mathbf{I}\end{array}\right|$ & $\begin{array}{c}\text { Case } \\
\text { II }\end{array}$ & $\begin{array}{c}\text { Case } \\
\text { III }\end{array}$ & $\mid$\begin{tabular}{|c|} 
Case \\
IV
\end{tabular} & Case \\
\hline 1 & 16.6 & 9.4 & 11.8 & 13.4 & 13.6 & 81.4 & 89.0 & 78.4 & 82.7 & 81.9 & 2.0 & 1.6 & 9.8 & 3.9 & 4.5 \\
\hline 2 & 13.9 & 8.0 & 12.7 & 11.8 & 8.8 & 84.0 & 90.0 & 80.0 & 85.4 & 84.8 & 2.1 & 2.0 & 7.3 & 2.8 & 6.4 \\
\hline 3 & 8.9 & 7.4 & 11.4 & 9.0 & 9.0 & 88.9 & 89.7 & 86.2 & $87.4 \mid$ & 82.5 & 2.2 & 2.9 & 2.4 & 3.6 & 8.5 \\
\hline 4 & 9.7 & 6.5 & 9.3 & 7.0 & 6.7 & 88.1 & 90.5 & 88.2 & 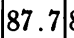 & 85.3 & 2.2 & 3.0 & 2.5 & 5.3 & 7.0 \\
\hline 5 & 9.8 & 5.6 & 8.7 & 6.3 & 6.0 & 86.8 & 91.2 & 87.9 & $|83.7|$ & 86.3 & 3.4 & 3.2 & 3.4 & 10.0 & 7.7 \\
\hline 6 & 8.7 & 5.4 & & 5.6 & 5.2 & 83.7 & 92.0 & & $84.1 \mid$ & $87.8 \mid$ & 7.6 & 2.6 & & $|10.3|$ & 7.0 \\
\hline 7 & & 6.3 & & 6.3 & 5.2 & & 91.4 & & $|82.6|$ & $87.7 \mid$ & & 2.3 & & 11.1 & 7.1 \\
\hline 8 & & & & 5.1 & 4.7 & & & & 84.2 & 89.4 & & & & $10.7 \mid$ & 5.9 \\
\hline 9 & & & & 6.6 & 6.6 & & & & 84.5 & 85.9 & & & & 8.9 & 7.5 \\
\hline 10 & & & & 5.9 & 4.9 & & & & 84.9 & 88.9 & & & & 9.2 & 6.2 \\
\hline Average & 11.3 & 6.9 & 10.8 & 7.7 & 7.1 & 85.5 & 90.1 & 84.3 & $|84.7|$ & 86.1 & 3.2 & 2.5 & 5.1 & 7.6 & 6.8 \\
\hline
\end{tabular}

1478 , and 1552. That the patient was able to maintain a state of nitrogen equilibrium during the last thirty-three days of the subcaloric diet is very unusual. There is some relationship between the loss of body nitrogen per day and the total loss of weight per day. In those cases losing weight more rapidly there was a greater loss per day of body nitrogen.

Source of heat during reduction. The percentage of total calories derived from protein, fat and carbohydrate is shown in table 4 . This percentage is based upon the assumed total metabolism which 
TABLE 5

Ketogenic-antiketogenic balance

\begin{tabular}{|c|c|c|c|c|c|c|c|c|}
\hline \multirow{2}{*}{ Case } & \multirow{2}{*}{$\begin{array}{c}\text { Period } \\
10 \\
\text { days } \\
\text { each }\end{array}$} & \multirow{2}{*}{$\begin{array}{c}\text { Total } N \\
\text { urine } \\
\text { plus } \\
\text { stool }\end{array}$} & \multicolumn{2}{|c|}{ Oxidized } & \multirow{2}{*}{$\begin{array}{l}\text { Keto- } \\
\text { genic } \\
\text { "K" }\end{array}$} & \multirow{2}{*}{$\begin{array}{l}\text { Antike- } \\
\text { togenic } \\
\text { "A" }\end{array}$} & \multirow{2}{*}{$\begin{array}{c}\text { Ratio } \\
\frac{\mathrm{K}}{\mathrm{A}}\end{array}$} & \multirow{2}{*}{ Remarks } \\
\hline & & & Fat & $\begin{array}{l}\text { Carbo- } \\
\text { hydrate }\end{array}$ & & & & \\
\hline \multirow{7}{*}{ I (El) } & & grams & grams & grams & $m M$. & $m M$. & & \multirow{7}{*}{$\begin{array}{l}\text { First nine days of con- } \\
\text { trolled low diet ex- } \\
\text { cluded. Period no. } 6 \\
\text { three days only }\end{array}$} \\
\hline & 1 & 127.6 & 1,778 & 100 & 7,375 & 4,120 & 1.79 & \\
\hline & 2 & 100.3 & 1,730 & 100 & 6,937 & 3,549 & 1.95 & \\
\hline & 3 & 64.0 & 1,812 & 100 & 6,855 & 2,871 & 2.39 & \\
\hline & 4 & 67.6 & 1,748 & 97 & 6,672 & 2,890 & 2.31 & \\
\hline & 5 & 65.7 & 1,652 & 148 & 6,323 & 3,081 & 2.05 & \\
\hline & 6 & 18.4 & 503 & 108 & 1,909 & 1,255 & 1.52 & \\
\hline \multirow[t]{7}{*}{ II (Ro) } & 1 & 94.9 & 2,560 & 104 & 9,730 & 3,935 & 2.48 & \multirow{7}{*}{$\begin{array}{l}\text { First ten days of con- } \\
\text { trolled low diet } \\
\text { excluded }\end{array}$} \\
\hline & 2 & 81.4 & 2,607 & 132 & 9,756 & 3,847 & 2.54 & \\
\hline & 3 & 78.6 & 2,702 & 197 & 10,053 & 4,206 & 2.38 & \\
\hline & 4 & 67.5 & 2,717 & 202 & 9,994 & 4,020 & 2.48 & \\
\hline & 5 & 51.7 & 2,400 & 194 & 8,749 & 3,474 & 2.52 & \\
\hline & 6 & 50.9 & 2,480 & 159 & 9,015 & 3,313 & 2.72 & \\
\hline & 7 & 62.4 & 2,583 & 145 & 9,484 & 3,530 & 2.68 & \\
\hline \multirow[t]{5}{*}{ III (Ho) } & 1 & 116.7 & 2,199 & 625 & 8,709 & 7,064 & 1.26 & \multirow{5}{*}{$\begin{array}{l}\text { First ten days of con- } \\
\text { trolled low diet ex- } \\
\text { cluded }\end{array}$} \\
\hline & 2 & 125.6 & 2,253 & 465 & 8,984 & 6,381 & 1.41 & \\
\hline & 3 & 112.5 & 2,421 & 150 & 9,429 & 4,465 & 2.10 & \\
\hline & 4 & 85.8 & 2,330 & 150 & 8,850 & 3,881 & 2.28 & \\
\hline & 5 & 82.6 & 2,378 & 210 & 8,972 & 4,176 & 2.15 & \\
\hline \multirow[t]{10}{*}{$\mathbf{I V}(\mathbf{K i})$} & 1 & 133.0 & 2,340 & 250 & 9,356 & 5,385 & 1.74 & \multirow{8}{*}{$\begin{array}{l}\text { First five days of con- } \\
\text { trolled low diet ex- } \\
\text { cluded }\end{array}$} \\
\hline & 2 & 109.5 & 2,260 & 165 & 8,847 & 4,398 & 2.01 & \\
\hline & 3 & 81.9 & 2,272 & 215 & 8,612 & 4,130 & 2.08 & \\
\hline & 4 & 66.1 & 2,360 & 325 & 8,756 & 4,478 & 1.96 & \\
\hline & 5 & 59.0 & 2,220 & 600 & 8,205 & 5,786 & 1.42 & \\
\hline & 6 & 51.0 & 2,161 & 602 & 7,922 & 5,598 & 1.42 & \\
\hline & 7 & 55.6 & 2,082 & 639 & 7,697 & 5,852 & 1.31 & \\
\hline & 8 & 44.0 & 2,080 & 600 & 7,574 & 5,408 & 1.40 & \\
\hline & 9 & 56.8 & 2,075 & 500 & 7,685 & 5,078 & 1.51 & Period no. 10 seven \\
\hline & 10 & 35.4 & 1,458 & 360 & 5,354 & 3,541 & 1.51 & days only \\
\hline \multirow[t]{10}{*}{$\mathbf{V}(\mathbf{K r})$} & 1 & 117.4 & 2,004 & 250 & 8,048 & 4,883 & 1.65 & \multirow{10}{*}{$\begin{array}{l}\text { First nine days of con- } \\
\text { trolled low diet ex- } \\
\text { cluded }\end{array}$} \\
\hline & 2 & 74.6 & 2,047 & 350 & 7,767 & 4,608 & 1.68 & \\
\hline & 3 & 76.3 & 1,997 & 469 & 7,603 & 5,266 & 1.41 & \\
\hline & 4 & 57.9 & 2,137 & 396 & 7,909 & 4,593 & 1.72 & \\
\hline & 5 & 50.1 & 2,046 & 413 & 7,518 & 4,466 & 1.68 & \\
\hline & 6 & 41.4 & 1,990 & 359 & 7,240 & 3,962 & 1.83 & \\
\hline & 7 & 40.1 & 1,916 & 353 & 6,972 & 3,856 & 1.81 & \\
\hline & 8 & 34.3 & 1,879 & 282 & 6,788 & 3,329 & 2.04 & \\
\hline & 9 & 47.1 & 1,740 & 347 & 6,439 & 3,866 & 1.66 & \\
\hline & 10 & 34.6 & 1,772 & 280 & 5,424 & 3,261 & 1.66 & \\
\hline
\end{tabular}


has been estimated to be 20 per cent greater than the basal metabolism. In three of the five cases protein averaged to supply less than 10 per cent of the total calories. The greatest average was 11.3 and the smallest 6.9 per cent. In all cases more than 80 per cent of the total calories were derived from fat, the average in case II being 90.1 per cent. Carbohydrate averaged to supply from 2.5 to 7.6 pert cent of the total'calories.

Ketogenic-antiketogenic balance. The ketogenic-antiketogenic balance is tabulated in table 5. The factors are expressed in millimols employing the values as stated by Shaffer (4) when based upon the assumption that one molecule of glucose is antiketogenic for one molecule of acetoacetic acid. The constancy of the ratios in consecutive ten day periods speaks strongly for the justification of the assumption that little glycogen was available in the body at the beginning of the accepted experimental periods.

In all cases the ratio of the ketogenic to the antiketogenic molecules exceeds $1: 1$. In case II, the same ratio consistently exceeds $1: 2$, and it should be noted that the experimental periods extended over seventy consecutive days. In all cases during these accepted experimental periods there was no detectable ketosis.

\section{DISCUSSION}

The above data are difficult to coördinate with the present conception of the ketogenic-antiketogenic balance. The findings in case II alone, where for seventy consecutive days a molecular ratio exceeding $1: 2$, Shaffer's (7) latest in vitro analogy, was oxidized without ketosis, reopens the question of the accuracy of the fundamental conception of the ketogenic-antiketogenic balance. Shaffer's (7) idea, based upon expected calculations only, that the ketogenic molecules from protein were underestimated by fifty per cent would make the reported ratios still higher.

That the human body has the capacity for adaptation has been suggested by Joslin (9) and he further has stated that there is most likely an essential difference between the ketonuria of the diabetic and the non-diabetic individual. Folin and Denis (10) in studies upon two obese women during successive fasts, also came to the conclusion that the human organism is capable of adaptation. They 
noted that with repeated fasting periods habituation to the complete oxidation of mobilized body fat followed. Considered from the viewpoint of comparative physiology it was a contributing observation that the dog and rat are very resistant to a fasting ketosis (Levine and Smith (11), Wigglesworth (12)). Baer (13) has reported a ketonuria with fasting in the monkey, but Harding and Allin (8) failed to produce ketonuria in a Dalmatian dog excreting uric acid either by fasting or by diets high in fat. The susceptibilities of puppies to ketosis, clearly shown by Allen (14), while the adult dog is very resistant, Harding (8) states may be "an expression of the non-development of the physiological regulatory mechanism until adult life."

The possibility that glucose exerts its ketolytic action as a triose was first recognized by Lusk (3) but still remains unproven.

In recent years more and more evidence has been accumulating to the effect that the normal and the diabetic individual may be able to convert fat into carbohydrate. Lawrence (15) has recently called attention to the evidence that by far the greater percentage of one's total metabolism, both in the active and resting state, is due to muscular activity, and that in muscular activity carbohydrate is the only substance known to be burned. This was shown by Krogh and Lindhard (16) through respiratory quotient studies, and has been confirmed by Furusawa (17) in a study of the rate of fall of the respiratory quotient after exercise. Similar data has been presented by Hetzel and Long (18) working with the diabetic individual with a lowered glycogen reserve. Finally, Burn and Marks (19) have published well controlled experiments which show that the perfusion of a liver removed from the body with defibrinated blood at $37^{\circ} \mathrm{C}$. results in the production of sugar in the perfusing fluid to an extent greater than can be accounted for by the disappearance of glycogen alone. The rate of sugar formation amounted to 2 to $4 \mathrm{mgm}$. per gram of liver per hour, and could be maintained at that rate for three hours provided a small amount of adrenalin be added to the perfusion fluid. Similar results were obtained using livers rendered almost carbohydrate free by feeding the animals with fat diets. The possibility of this excess sugar coming from lactic acid was excluded. Nitrogen studies controlled the amount derivable from protein. 
SUMMARY

Studies upon five cases of obesity maintained upon sub-caloric diets for prolonged periods of time are reported. Sufficient data were obtained to enable one to estimate with a fair degree of accuracy the mixture of foodstuffs actually catabolizing in the body.

In all cases the ketogenic-antiketogenic molecular ratio exceeded 1:1. In one case, No. II, the same ratio exceeded 1:2 throughout an experimental period of seventy consecutive days. In no case, during the experimental periods, was there any evidence of ketosis.

A discussion is presented of some of the various possibilities for an explanation of the above findings.

\section{BIBLIOGRAPHY}

1. Woodyatt, R. T., Jour Amer. Med. Assoc., 1910, iv, 2109. The Action of Glycol Aldehyd and Glycerin Aldehyd in Diabetes Mellitus and the Nature of Antiketogenesis.

2. Woodyatt, R. T., Jour. Amer. Med. Assoc., 1916, lxvi, 1910. Acidosis in Diabetes.

3. Lusk, G., The Elements of the Science of Nutrition, 3rd Ed., Philadelphia and London, 1917, p. 271.

4. Shaffer, P. A., Proc. of the Amer. Soc. of Biol. Chem. 15th Annual Meeting, Dec., 1920. Published in more detail, Jour. Biol. Chem., 1921, xlvii, 433. Antiketogenesis. I. An In Vitro Analogy.

5. Woodyatt, R. T., Trans Ass. of Amer. Phys., 1921, xxxvi, 269. Objects and Method of Diet Adjustment in Diabetes.

6. Wilder, R. M., and Winter, M. D., Jour Biol. Chem., 1922, lii, 393. The Threshold of Ketogenesis.

7. Shaffer, P. A., Jour. Biol. Chem., 1922, liv, 399. Antiketogenesis. IV. The Ketogenic-Antiketogenic Balance in Man and its Significance in Diabetes.

8. Harding, V. J., and Allin, K. D., Jour. Biol. Chem., 1926, lxix, 133. Ketosis in Pregnancy.

9. Joslin, E. P., Treatment of Diabetes Mellitus, 2nd. Ed., Philadelphia, 1917, 162.

10. Folin, O., and Denis, W., Jour. Biol. Chem., 1915, xxi, 183. On Starvation and Obesity, with Special Reference to Acidosis.

11. Smith, A. H., and Levine, H., Jour. Biol. Chem., 1926, lxvii, p. vi. Ketosis in the Rat.

12. Wigglesworth, V. B., Biochem. Jour., 1924, xviii, 1217. Studies on Ketosis: II. The Oxidation of Ketone Bodies by the Isolated Liver of the Rat. 
13. Baer, J., Arch. f. Exp. Path. u. Pharmakol., 1906, liv, 153. Untersuchungen über Acidose. II. Ueber das Verhalten verschiedener Säugetierklassen bei Kohlehydratentziehung.

14. Allen, F. M., Jour. Metab. Res., 1923, iv, 199. Experimental Studies in Diabetes. Series V. Acidosis. 4. Acidosis in Puppies.

15. Lawrence, R. D., Quart. Jour. of Med., 1926, xx, No: 77, 69. The Action of Insulin in Glycogen Formation and its Therapeutic Application.

16. Krogh, A., and Lindhard, J., Bioch. Jour., 1920, xiv, 290. The Relative Value of Fat and Carbohydrate as Sources of Muscular Energy.

17. Furusawa, K., Proc. Roy. Soc., Lond., 1925, xcviii, B., 65. Muscular Exercise, Lactic Acid, and the Supply and Utilisation of Oxygen. IX. Muscular Activity and Carbohydrate Metabolism in the Normal Individual.

18. Hetzel, K. S., and Long, C. N. H., Proc. Roy. Soc., Lond., 1926, xcix, B., 279. The Metabolism of the Diabetic Individual During and After Muscular Exercise.

19. Burn, J. H., and Marks, H. P., Jour. of Physiol., 1926, lxi, 497. The Production of Sugar in the Perfused Liver from non-Protein Sources. 